\title{
Chapter 5 \\ Transformations of the Teaching-Learning \\ Process Towards Inclusive Education \\ as a Result of the UDL Approach \\ Implementation
}

\author{
Jolanta Baran (1), Tamara Cierpialowska (1), and Ewa Dyduch (1)
}

\begin{abstract}
This chapter discusses the assumptions, implementation and deliverables of an action research project in a selected Polish class of integrated form. The main objective of the project was to trigger changes in the learning-teaching process based on the Universal Design for Learning (UDL) approach and thus promote inclusive education. The action research lasted one school semester. The empirical data, mainly qualitative, triangulating various sources of information and synthesising perspectives, were used to identify specific topics and threads identified in the gathered inputs, to present it in an orchestrated manner and to interpret it. It has been indicated that UDL approach implementation has a positive impact on the course of the teaching-learning process and optimises it to enhance the activity, commitment, self-reliance and responsibility of students and develops their cooperation, which breeds inclusion in education. Meanwhile, it stimulates teachers to change their mindset with a view to the essence of success in education and supports their daily practice.
\end{abstract}

Keywords Transformation of education · Universal Design for Learning . Teaching-learning process $\cdot$ Inclusive education

\footnotetext{
J. Baran $(\varangle) \cdot$ T. Cierpiałowska $\cdot$ E. Dyduch

Pedagogical University of Krakow, Krakow, Poland

e-mail: Jolanta.Baran@up.krakow.pl; tamara.cierpialowska@up.krakow.pl;

ewa.dyduch@up.krakow.pl
} 


\subsection{Introduction: The Theoretical Background for Changes in the Teaching-Learning Process Through Implementing the UDL Approach in the Integrated Class in Poland}

Inclusive education provides an opportunity to modernise the teaching process. However, it requires appropriate competences from teachers and opportunities for students to define their personal learning goals and their self-determination (EADSNE, 2011). In line with the key principles of improving the quality of education defined by EADSNE (2011), it is recommended that teachers use a constructivist approach in teaching and adequate solutions to make the course of lessons more flexible. Students are motivated to become active partners in the teaching-learning process and take on different roles related to cooperation with colleagues in heterogeneous teams.

The available studies confirm the effectiveness of promoting such solutions (Szumski, 2019; Mitchell, 2016). Moreover, some sources suggest strategies and approaches worth using to create favourable conditions for inclusive education, which includes the Universal Design for Learning (UDL) approach (Szumski, 2019; Baran, 2018; Mitchell, 2016; Olechowska, 2016).

Notwithstanding the inevitability of changing the education system in Poland, attention is drawn to the risk of maintaining the diversity of educational offered as a result of the emerging tendency to disapply the forms of education developed so far and to promote only one solution.

As a result of such an approach, one can see the "programmatic and organizational unification' in education (Janiszewska-Nieścioruk \& Zaorska, 2014, 24), and this phenomenon paradoxically denies reaping the benefits of student diversity, its inclusion and respect, as well as the use of different approaches in the teachinglearning process (Bąbka \& Korzeniowska, 2020).

In the opinion of many practitioners and researchers, inclusive education is already being implemented in Poland and on the basis of this claim comparative studies are carried out concerning, for example, the achievements of pupils from public, integrated and inclusive education. In the published research reports, however, it is difficult to find a description of how this inclusive education looks like in practice, what methods are used, etc. (Domagała-Zyśk, 2018).

The question, therefore, arises as to whether the measurements, analyses and prognosis made actually describe the facts they intend to describe. Consideration should also be given to the extent to which comparing different classes from different schools that consider themselves inclusive may be appropriate, if there are many different methods of teaching and learning available and they might be used.

Another issue refers to the research (action research) on practice that is directed towards implementing innovation and maintaining the changes in the evolutionary process. Introducing a change in teachers' work is always an evolutionary task. According to Arends (1995), two well-established theoretical orientations give direction to research in the process of change in educational institutions, that is: 
psychological, which takes into account people's reactions to change, and systems theory, which in our research is concerned not only with the analysis of the operational conditions of a particular school but also its status and place in the education system along with legal regulations. Moreover, it is known that the top-down implementation of reforms rarely brings sustainable and intended effects. This is the very important argument for success in transforming the practice of education.

The analysis of barriers identified through the UDL lens (see Fig. 4.1) presented in Chap. 4 becomes the starting point for the next cycle of action research of our project. This was aimed to promoting the application of the UDL approach and supporting teachers and students in this area with the aim of optimising the teachinglearning process in a diverse class team to change the education into inclusive education. It has been assumed that observing and documenting the ongoing changes will convince all participants of the survey about the value of the UDL approach as a line of thinking and organising education in a manner that favours its transformation. These benefits consist in creating a learning environment that is universal enough to enable each student, regardless of their abilities and difficulties, to participate fully in it and to make it a tool for optimal development, both individually and for the group to which they belong. Moreover, the aim was to transform the attitude of students from passive recipients of learning content into active learners, builders of their own knowledge, able to control, plan, organise and manage the process of their own learning, responsible, creative and able to solve various problems in cooperation with others. For teachers, on the other hand, the benefits might be seen in the remodelling of their thinking and pedagogical activity under the influence of the changes observed in the students, that is, the departure from the traditionally understood role of a teacher towards one who becomes a moderator and facilitator, creating optimal conditions for the teaching-learning process in a diversified group of students. This change is possible, among other things, thanks to the use of the UDL approach, as confirmed by available literature sources (Capp, 2017; Paiva de Oliveira et al., 2019; Scot, 2018), but also the results of our own research.

The main research problem was the essence of the change taking place in the teaching-learning process, so an answer was sought to the following question: How is the teaching-learning process and the reflection of teachers and students on this subject changing as a result of UDL approach implementation?

As a result of joint discussions with teachers, management and students, permission was obtained to continue the research project and make an attempt to implement certain modifications (consisting of UDL approach implementation). The impulse to launch changes in the teaching-learning process in the class under study was to guide teachers by providing them with knowledge about the UDL approach (which was expanded in subsequent periods), indicating specific UDL approaches and stimulating their motivation to that extent. It was possible because teachers and students showed, despite the previously mentioned concerns, openness and readiness to work. Moreover, the teachers showed awareness of the upcoming changes in the education system and its transformation towards inclusion. 
This was possible, among other reasons, because in the course of regular meetings of university researchers, teachers and students, we created a kind of community and learned from each other. We learned about the concerns experienced by other participants in the change that had started and, most importantly, we strengthened each other by sharing our constructive ideas. The mutual learning had not only a local dimension but also an international one-through visits to partner universities and schools, we were able to learn from each other's good educational practices, and more broadly, to learn a new view of diversity. In this way, we began to see/ understand student diversity much more as a value, which in turn convinced us more and more that inclusion was the right direction for changes in education.

Analyses carried out under the action research allowed capturing the changes that took place during Polish, math and history classes under the influence of the UDL approach implementation. These changes concerned, inter alia, enhancement of students' awareness of lesson objectives and providing them with opportunities for different ways of meeting lesson objectives and the related diverse forms of work.

Modifications made by the teachers resulted in a gradual departure from wholeclass teaching and the involvement of students in teamwork. Students became more and more consciously involved, thus becoming increasingly active learners. As they said themselves, they felt motivated when the usefulness of the acquired knowledge was shown to them and also when options to perform and express themselves were made more attractive through their diversification.

It should be noted that teachers began to identify factors conducive to the implementation of the UDL strategy. One such factor was the ability to combine two lesson hours into one block, which created an opportunity to act more freely in the lesson and at the same time to achieve the goals more fully. Another factor noticed by the teachers was the structuring of the students' activities by defining transparent rules of in-class work.

Supported by long-term counselling, teachers and students alike began to see the value of change in the implementation of the UDL approach. This, in turn, led to the disappearance/reduction of fears of ongoing changes.

At the same time, the teachers did not give up on noticing the barriers hindering UDL approach implementation. What is more, their formulation indicated a more thorough analysis of the current experience and confronting external obstacles resulting from the formal and legal solutions in force in the Polish educational system and (limited) resources (e.g. classroom equipment, teaching aids) at their disposal. Also, a barrier was the resistance of students to entering into new relationships for cooperation with other students, as they clearly preferred work in permanent teams.

Faced with these barriers, teachers and students adopted an active attitude, that is, they attempted to overcome them. The visible commitment and satisfaction of students became motivating for teachers. 


\subsection{Research on How the Teaching-Learning Process Changes in Implementation of the UDL Approach: The Example of One Integrated Class in Poland}

Even though a greater chance of success is assured by innovative grassroots initiatives proposed by a specific team of a given establishment that is known locally and that build greater trust than external reformers, we need to consider barriers that might appear. Thus, according to theoretical and empirical premises (Arends, 1995; Baran, 2000), the following barriers could be expected in UDL approach implementation in the selected class for research on the teachers working in it:

- Teachers of a given school are sceptical about a method tried elsewhere and consider it less reliable.

- Teachers have more confidence in the reformers they think they know about their local conditions (school, local, cultural, etc.).

- External persons, that is, scientists and researchers, the representatives of institutions who do not belong to a certain school, seem unreliable to the teachers.

- The introduction of such methods, which are based on at least partial knowledge of the changes introduced by local participants, is more effective.

Moreover, in accordance with the phases (Arends, 1995), of teachers' attitude towards innovation, that is, awareness, information, personalisation, action, consequences, cooperation and rationalisation, as specified by Fuller, it was considered of great importance that the duration of attempts to apply elements of the UDL approach, the frequency of contact of researchers with them and the reaction of students to changes in the way they work in lessons will be of great importance. This means that for the research it could be a good direction to study the teachinglearning process while implementing an innovation, to monitor teachers' and students' activities during lessons and to observe whether they are aware of the transformations both in their teaching-learning activities and their interactions and whether they discover them as useful, comforting and bringing them any kind of success. These factors might support the positive perception of the changes and willingness to continue innovation both by teachers and students despite the origin and nature of new strategies used during lessons.

The main research question was formulated: How is the teaching-learning process and the reflection of teachers and students on this subject changing towards inclusive education as a result of UDL approach implementation?

Due to the action research methodology, the action plan was designed for:

- Initiating and encouraging teachers and students to modify their existing routines during lessons, including the following:

- Making students aware of the objective(s) of the lesson(s) and emphasising an option for practical application of the knowledge gained at school in real life

- Suggesting to teachers that they should enable students to choose methods for achieving their goals, for taking actions and expressing themselves 
- Giving the choice of the work style (individual, in pairs, in a small group formed by students themselves), reinforcing cooperation between students

- Initiating reflective assessment of the teaching/learning process by teachers and students as a result of the UDL strategy implementation

After a period of actions, their next steps were included in the plan:

- Training teachers to use different, more innovative and diverse ways of assessing student performance

- Training students in self-assessment and self-control (encouraging them to move away from external motivation and to apply internal motivation)

- Joint development of a 'lesson guide' as a tool for activating students and helping to stimulate self-reflection (reflective learning)

The main focus was placed on implementation of some UDL strategies by teachers, suggested by researchers, and above all:

- Focusing on giving students the objective(s) of the lesson

- Giving students a choice to achieve that objective-making different ways of taking action available to the students

- Encouraging cooperation

- Encouraging and mobilising teachers to plan and implement education taking into account the UDL principles

- Providing methodological support to teachers and ongoing discussions on problems arising during class work

The selected four school teachers, under the guidance of researchers, started to implement the UDL approach in one integrated class of VI grade. It has been assumed that following the instruction of researchers, using the UDL approach in the classroom will improve students' interest in a given subject (Polish, mathematics, history) and improve their motivation to learn and become active learnersexperts in their own/independent learning.

Regular observations, talks and interviews generated quite rich inputs, confirming the changes were taking place. Their clear manifestation began to occur approximately in the middle of the research. However, at the beginning, during the first regular visits to the school, interviews with the teachers indicated clear resistance to continuing the work strategies proposed to them. The attitude of uncertainty and lack of conviction as to the need for work efficiency in compliance with the UDL assumptions is expressed by the words of one of the teachers during the debriefing after one of the first lessons:

Teacher Cecil: I'm not sure if everyone has understood the lesson objective. This is difficult for many students in this class. (Reflection with researcher, 29)

Other teachers wrote in the survey form summarising their classes:

Teacher Bella: There was some noise that sometimes disturbed. (Reflection with researcher, 28)

Teacher Agnes: Usefulness of the knowledge gained during class ... maybe they noticed ... (Reflection with researcher, 27) 
When arguing that there was no guarantee of success in the initiated activities, teachers usually referred to specific examples, that is, difficulties of certain students in school operations, their disabilities and the need for a personalised approach. They formulated barriers:

Teacher Cecil: The barrier (during the observed lesson) for everyone was the behaviour of a student who does not control himself in stressful situations. It hampers concentration of other people. Students' activity is directed at something else (rather than at the lesson content). (Reflection with researcher, 29)

Teacher Agnes: Writing and keeping up with work is problematic for some students. (Reflection with researcher, 27)

Teachers' statements show that in their professional experience they focus too much on the students' difficulties and their weaknesses, which can be a major barrier to a positive perception of possible good changes as a result of implementing innovation in the teaching-learning process. In showing external difficulties, they probably find an excellent justification for their feelings of comfort, which might be supported thanks to the teaching routines they use.

The analysis of the content of all the collected materials, after the final agreement of the researchers, allowed the identification of specific, further presented categories of problems/phenomena that emerged as a result of the UDL approach implementation into the teaching-learning process in Class VI. They were arranged at two levels as main topics/themes and more specific sub-themes.

\section{Perception of the Change Value}

The Sense of Realising es The teachers, despite their resistance, observed the phenomena occurring during their work with students in the classroom and referred to the specific actions proposed to them as part of the UDL approach. One of the signs that teachers began to draw their own conclusions appeared in the following reflection, signalling the mobilisation for change:

Teacher Bella: I think that the students did not even pay attention to the objective of the classes (...) Next time I'll try it differently-I'll emphasise the objective of the classes and the need to carry out such classes. (Reflection with researcher, 28)

Only 2 weeks later, it turned out that in a written report after the lesson, the teachers had already expressed their confidence in the fact that the students understood the objective of the lesson, but still had doubts as to whether the way it was presented was appropriate and whether all the students liked it.

After a month of regular classroom visits in a personal interview, one of the students said after history classes:

Patryk: Yeah, I knew what the point of the lesson was... but I liked it because the teacher asked a lot of questions to everyone. (...) It was worthwhile learning it, because it can be useful in real life to know where you come from ... there were cool pictures during presentation. (Reflection with researcher, 20) 
Kamil: The teacher explained exactly what were they going to do. (Reflection with researcher, 21)

Thus, the value of change was soon to be seen, including, first of all, the sense of making the objectives of the lesson/learning and adapting the ways of presenting them to the needs of students.

Teacher Cecil: I think the students knew that they would need this knowledge during the test. They took active participation in the classes. (Reflection with researcher, 29)

Kamil: You (the teacher) said exactly what we will know after the lesson. (Reflection with researcher, 21)

As the lessons followed, it became increasingly apparent that teachers were consciously directing their students towards explaining the purpose of the lesson in combination with demonstrating the usefulness of the acquired knowledge, and towards presenting and making available to the students the different ways of achieving it. The following teacher's comment was noted:

Teacher Bella: I think that there as a sign of growing awareness-a different approach stimulates curiosity, activity. (Reflection with researcher, 28)

\section{Perception of the Sense of Showing the Practical Application of Knowledge and}

Skills One of the questions addressed to the teachers concerned the assessment of whether the students had noticed the usefulness of the knowledge acquired during the lesson and was connected with the request to determine whether the students were motivated for the activity. One teacher's reply indicates that he saw a close link between these issues and the proposals for action made to the students:

Teacher Agnes: Some of them certainly (by implication: they saw the usefulness of the knowledge gained in the lesson and were motivated), especially as they like group work and 'guessing' elements (...) In my opinion, it is important for students to be able to apply their knowledge in practice. It is a sign of content understanding. (Reflection with researcher, 27)

The students' statements on this issue are also significant:

Mira: This could come in handy in an adult life. If we gonna have our kids one day, it'll come in handy because we can explain to them. (Reflection with researcher, 19)

Igor: I liked it because I know how to connect what was (learned in history) with what is now (he sees the connection between past and present). (Reflection with researcher, 24)

The teachers, using the knowledge, but also the various teaching aids proven in their experience, started to adapt them to the assumptions of UDL and, in principle, did not expect any suggestions in their decisions about these actions or about the forms of work with students. In discussions with researchers, they often announced what they intended to do in the next lesson and usually demonstrated confidence in the validity of their plans. These conversations before, but most often after the lessons, confirmed to the researchers quite quickly that the teachers participating in the project do not need detailed instruction. Thanks to their competence and professional experience, they have begun to make changes to their routine in lessons in a smooth manner. It could be seen that their approach was strengthened by the higher activity and interest of the students and their growing responsibility for their own 
work. One of the teachers, when asked about changes in the students' awareness of the learning process, said:

Teacher Agnes: I think that every lesson brings something new. I want students to feel the sense of the work they are doing and the responsibility for it. (Reflection with researcher, 27)

\section{Satisfaction With the Different Forms of Action and Expression Available in Class and Their Effects With every consecutive lesson, teachers and students strove to continue gathering experience related to changing the in-class activity. Teachers signalled to the researchers that the students have started to ask themselves about the work method being implemented. Thus, the method has become visible and satisfaction expressed with the forms of activity, which were not completely new, but so far less frequently used. In an interview with a student, one can see his experience of a positive emotional experience:}

Researcher: Are you satisfied with what you did during this class?

Mira: Yes, and I had a lot of fun.

Researcher: Why did you have a lot of fun?

Mira: Well, because it wasn't difficult, it was just so... well... so interesting. (Reflection with researcher, 19)

One of the teachers wrote a lesson report and her own conclusions:

Teacher Bella: Students worked individually and in groups. Assignment level-varied. The students had to choose location and action plan. Students were highly active, everyone was working busily. A very interesting experience. (...) Initially the students did not have any ideas, they used ready-made examples, but their creativity was stimulated during the classes. (...) I will try to do the same with the lesson (addition: from the next topic), but I will prepare the 'grounds' by presenting more examples. (Reflection with researcher, 28)

The remaining teachers confirmed the experience that the students acquired in order to gain knowledge on their own, which gave them methods of action, bringing them satisfaction:

Teacher Cecil: (Students) already know that there are different ways of gaining knowledge (watching, listening, movement, own creation). (Reflection with researcher, 29)

Teacher Agnes: I'll use activation methods. (Reflection with researcher, 27)

Another example of a student's satisfaction with a class, expressed during an interview:

Lucek: Oh, cool... very good explanation. (...) The class was held very well, I think it might not have been better. (Reflection with researcher, 23)

The same student, when asked after the next lesson about the means by which he chose to work and why, said:

Lucek: I picked up a map because I read ... I prefer to work with the map than with the text (...) Although I don't like (the name of the object), I really like this way (action). (Reflection with researcher, 23) 
Appreciation of the Cooperation Value Conventional teaching is primarily whole-class teaching, with the predominance of collective or individual work. This is also confirmed by the statement of one of the teachers:

Teacher Agnes: We teachers like this kind of whole-class teaching (...) it is also economical, conventional teaching, in the form of chatting, lecturing; we save time. (Reflection with researcher, 27)

However, group work, although it was not unknown to the teachers or their students participating in the project, did not occur very often during classes. The reasons for this fact will be further explained, and attention will be paid here to appreciation of and breaking resistance to the group work by the participants of the teaching-learning process in the surveyed Class VI. Our observations at the project onset showed that the teachers were not very keen on following up the experience of organising students' work in groups. Many times they emphasised in their interviews with researchers, most of whom have already had at least a dozen or so years of experience, that they appreciate the order in the lesson and a kind of silence that not only promotes concentration of students, but is even necessary for some of them, due to certain difficulties in functioning, and preferred by others:

Igor: It's not that I don't like them (other students). I just like to have peace and quiet, because sometimes when you work with someone, others make noise and sometimes there are arguments. (Reflection with researcher, 24)

After the first lessons, the teachers clearly pointed out the shortcomings of group work:

Teacher Cecil: Some students had a problem with group communication-(there were) different ideas for a drawing (project)—(overcoming difficulty is) ability to compromise. (Reflection with researcher, 29)

Teacher Agnes: I'll try to achieve greater, superior work discipline. (Reflection with researcher, 27)

This statement showed that the students need training in collaborative techniques in a group, that finding compromise is an important skill they should learn and that the opportunity to do so is provided by working in a group.

Gradually, both teachers and students, appreciating the various qualities of group work, paid less attention to emerging difficulties in cooperation and sought to maintain this form of activity, necessarily working out ways to reach a compromise. Both teachers and students began to point out those qualities that were related to the development of: cognitive competence-acquiring and verifying knowledge, skills (practical knowledge processing), social skills-learning to cooperate, share knowledge and help.

Teacher Cecil: The idea of group work (joint project-drawing) proved to be beneficial in this topic. The students memorise the contents of the lesson in a pleasant manner. (...) The work was creative; they could plan themselves where their building will be (the facility specified in the task). (Reflection with researcher, 29)

Teacher Agnes: They (the students), thanks to the fact that they can work in pairs or small groups learn to cooperate, and this is very important in later life. (Reflection with researcher, 27) 
Interestingly, the students talked much more about group work than the teachers, but it should be noted that the questions addressed to them were worded in such manner that they were directly related to this problem.

Kamil: It's worth it, because if you say something wrong, another person can think along with you. (Reflection with researcher, 21)

Adam: I could learn something and pose questions to others. (Reflection with researcher, 26)

Patryk: You can learn to be ingenious, for example how to work in groups and make something up. (Reflection with researcher, 20)

Adam: Because we can work together, get to know one another, to learn what are our strengths and weaknesses. For example, I know that $X$ is better with inventing things, and performs worse when he writes and draws. (Reflection with researcher, 26)

Patryk: (By working together) you can learn and help one another (student). (Reflection with researcher, 20)

Lucek: Well, it's worth it, because in the future it may come in handy at work too, we're not likely to work alone. (Reflection with researcher, 23)

\section{Identification of Factors Conducive to UDL Approach Implementation}

In the focus group interview, carried out to sum up the implementation of the project, important observations of the teachers were collected, in which they expressed, among other things, their satisfaction with the acquired experience of UDL approach implementation. Among the comments made, interestingly enough, there were clearly positive conclusions. Moreover, one might venture an opinion that on the basis of the arguments presented and the positive emotions felt in the teachers' voices, that they were not only satisfied but also pleasantly surprised by the changes in activity observed in the classroom, and even managed to identify some kind of feeling of comfort, instead of the fatigue they experienced while working with students. The comment about traditional teaching by one of the teachers seems to be significant:

Teacher Cecil: To date I have been terrified by the fact that some children did not take anything out of class. .... When we have conventional class, I can't always mobilise them. (Reflection with researcher, 29)

The analysed reflections of the teachers from the recorded interview are grouped into the themes discussed.

\section{Extending the Time for the Lesson Topic by Combining Two Lesson Hours into}

One Unit The statement, as quoted earlier, that traditional teaching is 'economic' has been contrasted by teachers using so-called time management with the UDL approach in the following statement:

Teacher Bella: I can do this (implement UDL strategies) only if I have two hours in a row with them. I'm happy that the headmaster gave me that extra hour on Tuesday (for my subject). (Reflection with researcher, 28) 
Other teachers shared this conviction, admitting that a 45-min lesson unit is not enough to complete the topic, especially as there are often unforeseen organisational or educational problems, and different information is given to students, which takes time. We have to admit that a teacher cannot and should not wait to address certain problems until a weekly class meeting ( $1 \mathrm{~h}$ a week), as a result of which, after discussing some important issues, for example, educational issues, he or she has reduced time for topic discussion and resorted to so-called economic strategies. The opinions of all teachers involved in the project were unanimous in the sense that if a teacher has a block of two classes equal to $2 \mathrm{~h}$ on a particular day, he or she can perform more effectively while implementing all lesson phases:

Teacher Cecil: (Teacher) has (time), can approach any student. (Reflection with researcher, 29)

Teacher Agnes: Before (students) do some work (during the first hour), then during second hour (the teacher) will present a summary, have a discussion, make an assessment. (Reflection with researcher, 27)

In the absence of such a daily schedule, one of the teachers has adopted the following solution:

Teacher Cecil: When there's a lesson and there's no time for debriefing, I'll do it in two days, when I have a class. ... I don't think it's a bad thing. (Reflection with researcher, 29)

The specific race against time seems to be a burden for teachers; they would like to have the opportunity to have individual contact with the student during the lesson to be able to give students more time for action, as they know how it is important for the sustainability of knowledge and the students' commitment to the teachinglearning process. From the teachers' words a postulate emerged that timetables should be reorganised in such a manner that it would be possible to work with forming lesson units, that is, that there are two lessons on a certain topic on a certain day, the so-called unit. This would provide a chance to hold classes following the UDL approach with a feeling of comfort enjoyed by the teacher and by the students.

\section{Structuring the Students' Activities by Clearly Stating the Objective and Formulating Transparent Rules of In-class Work Teachers were asked to clearly formulate and give students the objective(s) of the classes and give them a choice of how they wanted to achieve such objective(s). In the debriefing interview, they admitted that at first, they were surprised that researchers cared so much about this, but they also admitted that over time they observed that taking care of these condi- tions clearly improves students' motivation:}

Teacher Bella: At the beginning I wondered why the researchers want to ... repeat, repeat, again and again ... But there is something about it ... And in fact, why they need it (what they will learn in class) ... and that is the source of their motivation. ... This project has helped me understand many things. (Reflection with researcher, 28)

Teacher Cecil: Kids like to know — what for? (Reflection with researcher, 29)

Teacher Agnes: It is necessary because it is visible even from the students ... to present this goal in a variety of ways, I can see that it really works ..., and this motivation is anchored in them somewhere-that it makes the whole effort worthwhile. (Reflection with researcher, 27) 
Closing the topic of the purpose of the lesson and using examples from various professional experiences, one of the teachers, followed by the others, stated:

Teacher Cecil: But it's not that new. (Reflection with researcher, 29)

During their interviews, while talking about various topics, the teachers pointed out the importance to them of discipline in the classroom, in which they referred not only to the lack of chaos and noise but also to the specific order of the lesson, the lack of disturbances caused by unexpected difficult behaviour of some students, visible concentration and work and a culture of discussion. This means that they feel responsible not only for organising but also for managing and fully controlling the teaching-learning process.

Teacher Cecil: (When) I'm going for classes, (I think) I'll see if they are in the mood, what's up ... but I'm putting the situation in order, (I care about) what I want to achieve and what they'll learn from this class. (Reflection with researcher, 29)

The fear of chaos in the classroom as a result of the UDL approach made them consider the introduction of contracts/principles useful, as they themselves gave 'voice' to the students, relying on them for a fully predictable lesson as a result of the introduction of various forms of work, and above all, group work. An illustration is the following statement:

Teacher Agnes: I cut short all off-topic comments, because they like to talk, and some people find it very disturbing. That's why I write these ground rules on the board, how to behave (while working in class). (Reflection with researcher, 27)

In the interviews, the students commented on the situations that occurred during classes and their course as follows:

Hubert: It wasn't loud, ... everybody could say something. (Reflection with researcher, 22) Adam: It went well, because we knew what to do and $Y$ (a student) didn't disturb. (Reflection with researcher, 26)

Patryk: I didn't understand everything right away, so our teacher had to explain it. (Reflection with researcher, 20)

Hubert: The students are more polite than last year and the teachers are doing their best. (Reflection with researcher, 22)

Students' statements confirm that if teachers follow UDL rules by structuring their activities while formulating the objective clearly and stating transparent rules of in-class work, then the students are satisfied and positively relate to the teacher's expectations, but at the same time have a sense of free choice in their success; they feel motivated to act and also to cooperate with others in the classroom. 


\section{Identification of Barriers Preventing Change and Striving to Overcome Them}

The question addressed directly to the teachers, during the focus interview, concerned the current and anticipated barriers to changes in the teaching-learning process. The discussion stirred by the question confirmed the shortcomings of the existing education system. The obstacles and difficulties mentioned explicitly, including those not fully named by the teachers, which may significantly limit the full application of the new/proposed solutions or may be a reason for giving up the initiated changes, are presented by the researchers in the description below.

Time-Consuming Planning and Preparation of Classes According to the UDL Rules-The Effects of Students' Work Are Not Always Equal to the Teacher's Workload Related to Class Preparation The feeling of making full use of the material prepared by teachers for students during classes turns out to be an important factor, combining the time-consuming work with the use of the UDL approach. If a work exercise does not stir students' interest, that is, nobody decides to do it, the teachers perceive this as a waste of time for its preparation, moreover, as an underestimation/lack of recognition of the proposed activity's usefulness/significance to knowledge.

Teacher Agnes: (It takes time) for the teacher to get prepared (for the classes), exercises, tasks of the proposal. ... It turns out that (students) do not always want to use/do them all. (Reflection with researcher, 27)

This example shows how important it is for the teachers to attain at once all goals that arise from the core curriculum during classes. Being aware that a certain knowledge has been 'discovered' during a particular class or that students have acquired a certain skill resulting from a planned task/exercise/activity form is a 'reward' for the teacher's time spent for class preparation.

Time Required for Class According to UDL Rules Accusing the UDL approach of time-wasting is related to the factor discussed above that is conducive to the application of the UDL approach, that is, the realisation of the class topic in a 2-hour unit. The accusation is nothing more than a belief, or perhaps rather a concern, about the low efficiency of work in line with the UDL approach assumptions. Unfortunately, teachers are convinced that the number of exercises performed in class shows effectiveness, as if they missed the value inherent in the quality of the activity, related to the independent pursuit of knowledge by students and their commitment to the learning process, which, as we know, bring much longer lasting results. However, what was important in the manner in which the teachers expressed their comments/barriers was not so much evaluating and negative argumentation as a kind of rational acceptance of their occurrence. Thus, an attitude is revealed that can be verbalised as follows: it is a fact that the barriers do exist, but one can still act. The following statement is evidence: 
Teacher Cecil: The lesson lasts only 45 minutes. This is very little time and prevents more interesting ways of working. (Reflection with researcher, 29)

Teacher Agnes: Certainly, the UDL approach makes the curriculum slower ... It is not efficient. (Reflection with researcher, 27)

'Dictatorship' of the Core Curriculum For many years now, public and scientific debate has focused on the criticism of the Polish school for its traditional approach to teaching methods and the rigorous requirement to implement the core curriculum, which is related to external control. Students after certain stages of teaching are subjected to examinations, which are developed by third-party education supervision units. The teacher is being held responsible for whether and how, that is, with what grade, the student passes these exams. In addition, the schools are ranked both at the local and national levels and such lists are published later on. In a focus group interview with the teachers, important statements were made:

Teacher Cecil: Students must learn everything (because it is), the core curriculum, not what interests them, what may come useful to them in life. (Reflection with researcher, 29)

This fact was discussed as another barrier hindering the implementation of UDL in the Polish schools. In order to strengthen opinions, it is worth referring here once again to the words already quoted indicating that teachers feel they are prisoners of the (education) system.

\section{Pressure Exerted by the Educational Authorities to Teach the Students Based} on the Overall Material The dictatorship of the core curriculum is connected with the rigorous adherence of the educational authorities to the deadlines for the realisation of the planned teaching material, which is additionally checked by external examinations. It is also common for students' parents to check whether teachers 'work effectively':

Teacher Agnes: If we give them (students) more flexibility, not everything will be mastered and the exam is required (core curriculum established by the Ministry of National Education). (Reflection with researcher, 27)

Misconception of the Teacher's Role Teachers feel overburdened with many professional duties as, in addition to the teaching process, they spend a lot of time on the bureaucracy involved in completing various school documents and those required by teaching supervision. The cooperation with the students' parents can be very arduous, especially since many of them, like education managers, hold teachers responsible for situations and objective difficulties arising in the teaching-learning process that is completely independent of them and their actions. The role of the teacher being confused with the role of other actors/systems related to the students and held equally responsible for them is a complaint made by one of the teachers:

Teacher Cecil: We are responsible for everything that happens at school, for instance: bad behaviour (of students), their poor grades. (Reflection with researcher, 29) 
Parents' Pressure to Prepare Their Children Well for the Final Exams The control of teachers' work by the students' parents manifests itself also in the pressure to ensure that their children learn first and foremost at school, allowing them to take their final exams without fear.

Teacher Agnes: Parents' expectations vary; some parents want us to do a lot of homework, whereas other parents believe that school does not mean everything in children's lives. (Reflection with researcher, 27)

Teacher Cecil: Parents ask if the material (curriculum) execution goes well and if (students) have mastered it well. (Reflection with researcher, 29)

Identifying 'Educational Success' With Being Ranked High The consequence of a student taking the final exam is to achieve a high score, and this requires not only knowledge but also so-called examination efficiency (Chrzanowska, 2015, 581; Gajdzica, 2013). These are the expectations of parents because most of them plan their child's future according to educational success, which is expressed by the student's achievement of the highest grades in (primary) school. High achievements become a guarantee of a student's admission to a specific secondary school that his or her parents have on their minds.

Teacher C: It is important for parents that their children are ranked high enough to enrol in secondary comprehensive school. (Reflection with researcher, 29)

Teachers feel strong pressure exerted by the parents and find that they are held accountable for the successes and failures of the student.

Students Disclose Desire to Cooperate Always Within the Same Team-Habit and Being Closed to New Relationships During the implementation of the UDL approach, the teachers offered their students various ways of getting into the group as a part of their joint work. Unfortunately, the students agreed to work in a team with a different composition only with great resistance. During interviews, they tried to convince the researchers in the following manner:

Lucek: If we cooperate with someone from the other end of the classroom, then ... most probably it will not work out. (Reflection with researcher, 23)

Adam: We could choose in which group we want to work. I worked with my crew. We're friends and after classes we see one another off. (Reflection with researcher, 26)

As in any community, there were also those students who were reluctant to cooperate and chose to act independently.

Igor: I prefer to work on my own. This is my favourite work style. During my next class, I would go for the same thing. (Reflection with researcher, 24) 


\subsection{Changes in Teachers' and Students' Perception and Reflection in Teaching-Learning Process of Inclusive Education by Implementation of the UDL Approach}

The results of the research can be summarised by a statement referring to the attitude that has started to be clearly visible in both teachers and their students: it is worth trying to introduce changes in the process of teaching and learning; it is worth trying to break the routine. One should not be afraid of changes because they bring positive results.

The research enabled us to capture evolving attitudes of teachers and students that have been revealed under the influence of UDL approach implementation during Polish, math and history classes. Teachers began to attach greater importance to making students aware of the lesson objectives, creating opportunities to differentiate the ways in which they achieve lesson objectives and more frequent use of different forms of work. This resulted in a gradual abandonment of whole-class teaching in favour of teamwork with student participation. Initially, teachers felt discomfort caused by more easy-going atmosphere during classes and the fear of failing to achieve the core curriculum within the prescribed timeframe. Over time, however, they and the students began to feel satisfied, especially with growing mobilisation of students to perform, and thus their motivation and activity during classes. As a result of these changes, the value of change was recognised.

Teachers reported that being aware of lessons/learning objectives works well and makes sense. During interviews carried out after Polish, math and history classes, the students revealed the awareness of the practical application of the knowledge they learned or they mentioned its usefulness for the future. They appreciated that teachers at the class beginning formulated specific objectives and identified the usefulness of what they later learned. The teachers and students clearly stated that it made sense to show the practical application of knowledge and skills.

Pursuant to the UDL approach, the teachers were given guidelines for thoughtful application of various forms of in-class performance and expression by the students. This led to the situation where, in addition to the strategy and workstyle developed by them in parallel to professional experience acquisition, they modified both inclass measures and the ways of involving students in activities (projects, models, schemes, drawings, student work in diversified and evolving work groups). Recognising and appreciating the outcome of these measures, students and teachers started to express their satisfaction with the availability of more diverse forms of in-class activities and expression.

The assessment of the outcome of the UDL approach application based on the empirical data collected during the research also applies to the identification of factors conducive to the undertaken implementation activities.

The teachers themselves mentioned the need to extend the time to complete the lesson subject by means of combining two lesson hours into one block and structuring students' activities on the basis of clearly defined goals and laying down transparent rules for in-class activities. 
By making a generalisation of the parts discussed and identified themes and subthemes in the statements of the teachers during the implementation of the research project, it can be concluded that the experience of teachers and students began to confirm the perception of the value of transforming the conventional teaching process into the students' learning process, understood in a constructivist manner.

This phenomenon should be noted, since it is desirable and expected not only due to the application of the UDL approach, but, above all, due to the recommendations for practice generated by a radical theoretical change in pedagogy, that is:

- Changes in the student's field of activity and the teacher's attention (a different area of control and self-control; orientation at the knowledge acquisition processes, not only performance-oriented; monitoring instead of controlling, etc.)

- Changes in the content, time and space management (in place of rigid management and an external plan, the principles of flexibility, content personalisation, wide availability of space and sources, etc., start to operate)

- Focus on individualisation (which turned out to be more knowledge-forming than collective teaching, which does not respect individual resources) (KlusStańska, 2019, 15)

In addition to the positive reflections of teachers coming from the reflection about the changes they observed in the teaching-learning process, and thus, changes taking place in students, it was noted that barriers hampering change were perceived, as well as the desire to overcome them.

Opinions formulated by teachers and reported inconveniences concerned, first and foremost, the time-consuming planning and class preparation according to the UDL rules. It was emphasised that the outcome of students' work is not always equal to the teacher's workload pertaining to class preparation. It can be assumed that teachers would not complain about the incommensurability of efforts and benefits if they were not burdened with various extra work, including in particular work related to formal documentation, drawing up various types of reports, etc. They did not consider the fact that with the acquisition of new experience they will develop economic strategies for lesson development in line with the rules of the UDL approach.

Another barrier mentioned by them was the overbearing nature of the core curriculum, that is, ministerial regulations with requirements for teachers in terms of the necessity to implement the core curriculum with all students within the formally prescribed timeframe. Additionally, the pressure from the education authorities to complete the whole curriculum made the impression of yet another barrier. This fact is indeed reflected, inter alia, in the applied external controls. The misunderstanding of the teacher role is another argument formulated by the teachers as evidence of imposing extra non-didactic duties on them. In their opinion, not only students' parents but also pedagogical supervision, impose expectations on the school management and teachers that go beyond their competences, which sometimes lead to undermining of their profession, for example, blaming only teachers for all student failures. Although this phenomenon is very complex and has a broad social and legal context, the belief expressed by teachers, although not without validity, does 
not take into account their attempts to limit their professional responsibility to only selected scopes of activities (Groenwald, 2013).

Teachers, referring to the expectations of their students' parents, define another barrier in the implementation of the UDL approach, which is the accountability of teachers for their performance, pointing to the pressure exerted by parents to prepare their children well for the final examinations.

The so-called examination efficiency is the nightmare of Polish schools, limiting the freedom of teachers to act, and forcing students to make great efforts. This phenomenon is accompanied by the association of 'educational success' with a high position in the ranking, which the surveyed teachers consider as another barrier in UDL approach implementation. Unfortunately, the Polish educational realities have not yet been able to escape such a vision of student, teacher and school success. The rankings are common and advertised in many social media, especially in the press and on the Web. They are also submitted and expected in the reports to the world authorities.

Synthesising this part of the research project, the difficulties in teamwork shown by the students randomly assigned to various work groups should be pointed out. Their statements and behaviour during lessons show that they were willing to cooperate, but only in a regular community of peers. They did not like to change teams and could not appreciate the value of the experience of working in a new team. This phenomenon leads to the conclusion that students show strong inclination to stick to their habits of working in a permanent team and are closed to new relationships.

To this conclusion, it is worth adding the teacher's symptomatic utterance made during the focus group interview:

Teacher Cecil: They (students) are thirsty for success. (Reflection with researcher, 29)

\subsection{Discussion and Conclusions: Teaching-Learning Process Changes Towards Inclusive Education Under Implementation of UDL Approach}

The final interpretation and generalisation of the results from the action research, which was divided into cycles, are presented in a reference to the scheme showing the mechanisms of identified and documented changes, as well as the factors determining their course (see Fig. 5.1).

As indicated by the research presented above, the source of the changes taking place is of great importance to the success of innovation. The process of change is influenced by both the factors identified inside the process and those functioning outside, providing the context for the changes taking place. Although the stimulus generally comes from outside, it depends on the actor to what extent, how and at what rate the change will take place (Lubrańska, 2004). Openness and willingness to change is an internal factor that should be considered as its basic engine. It is worth noting that openness and readiness to change is initially associated with 


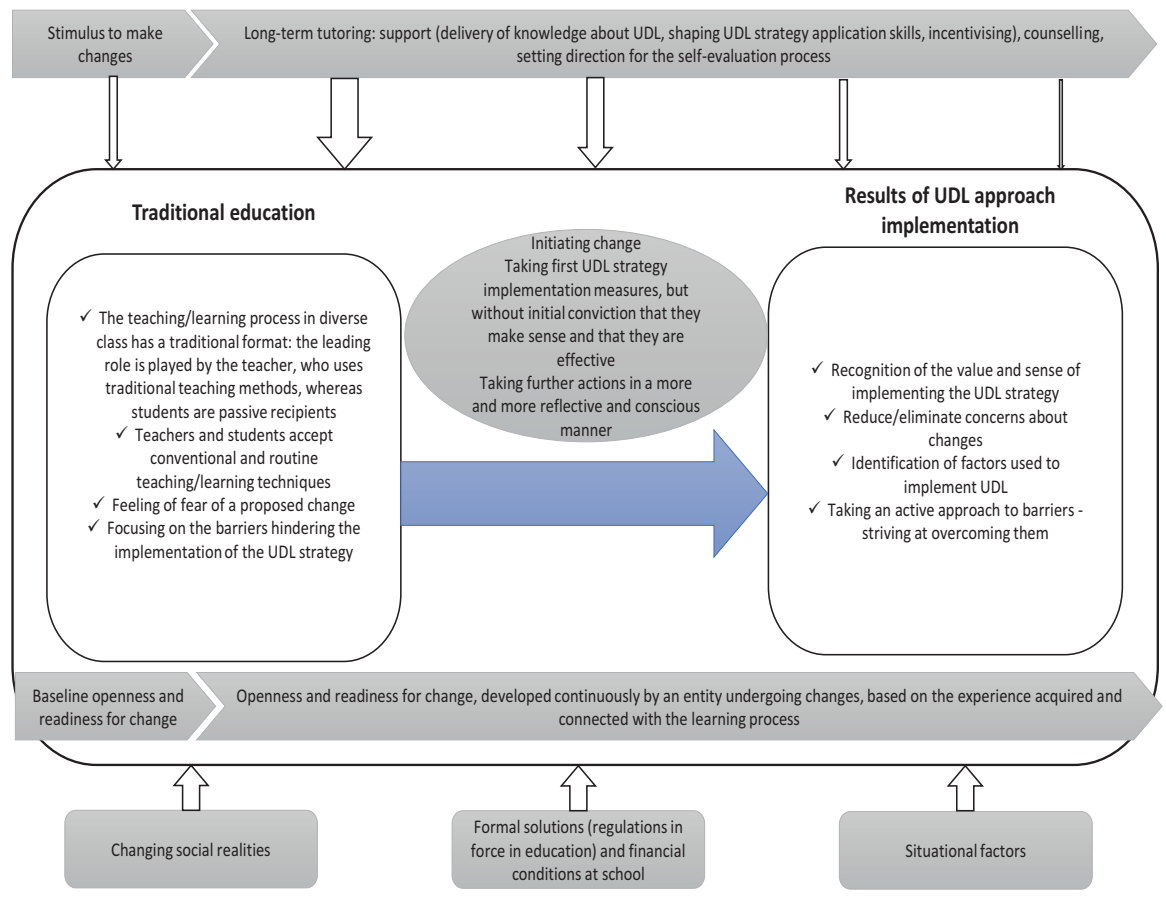

Fig. 5.1 Mechanism and determinants of changes in the teaching-learning process towards inclusive education under the influence of UDL approach implementation Key: White colour-mechanism of changes, Grey colour-change drivers, Vertical arrows at the top-diminishing thickness means declining share of tutoring

personality traits, and secondly, it is based on acquired experience and manifests itself in constant development of the entity (ibid.) generating the change. It is an essential feature in the lifelong learning process that characterises the existence of contemporary humankind. Readiness for change is connected with further internal factors, that is, undertaking/initiating an action, despite the initial lack of conviction about its meaning and effectiveness, then perceiving the value and sense of change, determination to continue innovative activities and finally experiencing the positive impact of the changes introduced in the teaching/learning process. Therefore, in order to make a change, it is important to take action, even without full preparation, because the effects of this action are mobilising.

Among the identified external factors that foster change using the UDL approach in the class studied was providing an impetus to take action, which was to invite teachers and students to participate in the project. Another factor that continued the impetus was long-term tutoring, which offered support to teachers and students (i.e. providing knowledge about the UDL approach, shaping the ability to work with selected strategies and maintaining motivation for further action), as well as advice and evaluation of results. An important external factor driving change is also the changing social reality, including the appreciation of such values as well-being, 
creativity, knowledge, responsibility and independence, cooperation and ability to solve contemporary problems (cf. Szempruch, 2012). The results of the conducted action research confirm that it is also important to create more favourable formal solutions, including modification of educational law and improvement of financial conditions of schools. In the presented research, a factor clearly hindering the course of change was the formal solutions in force in Poland, obliging the teacher to implement the 'overloaded' core curriculum and the system of external control to which the teacher is subject. This makes teachers afraid that if more flexible and innovative forms of action are introduced in the lesson, their work will be assessed negatively.

Analyses of the inputs collected through our own research are consistent with the findings of the professional teacher development model developed by Guskey (2002). Changes in education can be made through professional training and development of the teacher. However, this will happen when the teacher starts to perceive changes in student achievements and performance as a result of attempts to implement new strategies, etc. It is the changes taking place in students that change their beliefs and attitudes towards the proposed application of innovations and modification of their own actions in the student teaching and learning process.

The initiated changes would be hard to consider permanent if they were not confirmed by a need to continue the actions started. As with any process, the presented process of change in the teaching/learning system should continue and evolve in a manner that is relevant to the changing reality. The change in education is part of wider social processes and their transformations (Szempruch, 2012), so it is not possible to continue innovation in the teaching/learning system in a rigid manner in isolation from the social context of the operations of all entities involved in education (as evidenced by the global situation caused by the COVID-19 pandemic). The change in education is evolutionary by nature, although the resulting transformations may seem revolutionary in the sense that they seem to be reversing the current order of the teaching/learning process.

Given the great diversity of the needs and abilities of students in contemporary schools, it is necessary to strive to create the widest possible conditions for the successful implementation of inclusive education. The school should be an environment for all students to stimulate cognitive development and acquisition of knowledge for the twenty-first century, but also, and perhaps most importantly, a place to establish and develop relationships, especially with peers, including the ability to cooperate, solve problems and be open to diversity in the broadest possible sense. The implementation of strategies based on the UDL concept seems to be a good direction for changes that should be promoted in school education to prepare students to meet the challenges of the modern, ever-changing world.

The implementation of the educational process in compliance with the UDL assumptions makes education at every level:

- Available in an attractive form for every student, regardless of their difficulties

- Flexible in form, adapted to the student's preferences and abilities

- Intuitive and accessible to all, including students with limited competences

- Perceptually accessible for the students with impaired eyesight or hearing 
- Friendly due to its implementation in a space arranged to match the students' needs (e.g. limiting the number of stimuli and allowing for silence for those who need it)

- Uncomplicated due to the use of teaching materials that are easy to use (Domagała-Zyśk, 2017, 14)

An unquestionable value of inclusive education implemented under the UDL model is the opportunity for students to make choices in many different aspects, for example, the choice of specific objectives they want to pursue, the choice of the form in which they want to learn (individual, couple or group work), the choice of didactic means they want to use or the choice of forms of expression of acquired knowledge or skills. Therefore, the students have the opportunity-through genuine commitment-not only to become responsible for their own education process but also to help their schoolmates by means of peer tutoring.

In this context, the teacher's role is also changing. From the asymmetrical position of the one who teaches, he or she becomes a tutor and partner of the students in their own activity.

All of this, however, requires significant transformations of school reality. Is it worthwhile to make this effort? For the reasons mentioned above the answer is yes, by all means. However, one must face the fact that changes in education cannot be introduced using a top-down approach, or in a radical manner. School reality needs re-engineering. It is necessary to identify existing barriers, one by one, to reflect on them, take and modify actions, assess their effects and start the process of education reengineering from the onset.

\section{References}

Arends, R. I. (1995). Uczymy się nauczać [We learn teaching]. Warsaw: Wydawnictwa Szkolne i Pedagogiczne (School and Pedagogical Publishers).

Bąbka, J., \& Korzeniowska, R. (2020). Jedność w różnorodności w perspektywie edukacji inkluzyjnej oraz uczenia się we współpracy (Unity in diversity in inclusive education and collaborative learning). Człowiek - Niepetnosprawność - Społeczeństwo [Human-disabilitysociety], 2(48), 47-58. https://doi.org/10.5604/01.3001.0014.1671.

Capp, M. J. (2017). The effectiveness of universal design for learning: A meta-analysis of literature between 2013 and 2016. International Journal of Inclusive Education, 8(21), 791-780.

Baran, J. (2018). Kluczowe problemy w kreowaniu procesu edukacyjnego w klasie inkluzyjnej [Key issues in creating an educational process in the inclusive classroom]. In V. Kušnírová \& G. Vojteková (Eds.), Inkluzívne prístupy v edukácii detí a žiakov [Inclusive approaches in the education of children and pupils] (pp. 225-236). Ružomberok: Verbum.

Baran, J. (2000). Otwartość i gotowość nauczycieli do zmian systemu edukacji. [Openness and readiness of teachers to change the education system]. In A. Rakowska \& J. Baran (Eds.), Dylematy pedagogiki specjalnej [Special education dilema] (pp. 97-102). Kraków: Wydawnictwo Naukowe Akademii Pedagogicznej (Pedagogical Academy Scientific Publishers).

Chrzanowska, I. (2015). Pedagogika specjalna. Od tradycji do wspótczesności [Special education. From tradition to the present day]. Kraków, Oficyna Wydawnicza "Impuls" ('Impuls' Publishing House). 
Domagała-Zyśk, E. (2017). Projektowanie uniwersalne (universal learning design) w edukacji osób $z$ wada stuchu [Universal learning design in education for people with hearing loss]. In M. Nowak, E. Stoch, \& B. Borowska (Eds.), Z problematyki teatrologii i pedagogiki [From the issues of theatre theory and pedagogy] (pp. 553-568). Lublin: Wydawnictwo KUL (KUL Publishing House). https://www.researchgate.net/publication/313193980. Accessed 27 January 2019.

Domagała-Zyśk, E. (2018). Uczniowie z niepetnosprawnościami w szkołach ogólnodostępnych $i$ integracyjnych $w$ polskich badaniach naukowych. Część I - artykuły z polskich czasopism naukowych 2013-2017 [Pupils with disabilities in mainstream and integrated schools in Polish research. Part I-Articles from Polish scientific journals 2013-2017]. Warszawa: MEN (Ministry of Education Publishing House).

European Agency for Development in Special Needs Education (EADSNE). (2011). Kluczowe zasady slużące promocji jakości w edukacji właczającej - Zalecenia praktyczne [Key principles for promoting quality in inclusive education-Practical recommendations]. Odense, Denmark: European Agency for Development in Special Needs Education.

Gajdzica, Z. (2013). Kategorie sukcesów w opiniach nauczycieli klas integracyjnych jako przyczynek do poszukiwania koncepcji edukacji integracyjnej [Categories of success in the opinions of teachers of integration classes as a reason to seek the concept of inclusive education]. Kraków: Oficyna Wydawnicza "Impuls” ('Impuls' Publishing House).

Groenwald, M. (2013). Standardy moralne czy standardy wymagań? O moralnych aspektach pozoru $w$ szkole [Standards of morality or standards of requirements? On the moral aspects of school appearances]. In M. Dudzikowa \& K. Knasiecka-Falbierska (Eds.), Sprawcy i/lub ofiary dzialań pozornych $w$ edukacji szkolnej [Perpetrators and/or victims of bogus activities in school education] (pp. 131-150). Kraków: Oficyna Wydawnicza "Impuls" ('Impuls' Publishing House).

Guskey, T. R. (2002). Professional development and teacher change. Teachers and Teaching: Theory and Practice, 8(3/4), 381-391. https://doi.org/10.1080/135406002100000512

Janiszewska-Nieścioruk, Z., \& Zaorska, M. (2014). Prowłączające zmiany w systemie polskiej edukacji - nowe możliwości, ograniczenia i wyzwania [Pro-inclusive changes in Polish education system-New possibilities, barriers and challenges]. In Interdyscyplinarne Konteksty Pedagogiki Specjalnej [Interdisciplinary Contexts of Special Education], 4, 9-28.

Klus-Stańska, D. (2019). Wiedza osobista uczniów jako punkt zwrotny w teorii i praktyce dydaktycznej [Students' personal knowledge as a turning point in didactic theory and practice]. Kwartalnik Pedagogiczny (The Pedagogical Quarterly), 1(251), 7-20.

Lubrańska, A. (2004). Człowiek wobec zmian w organizacji [Man Vis-a-Vis changes in organisation]. Acta Universitatis Lodziensis Folia Psychologica, 8, 171-182.

Mitchell, D. (2016). Sprawdzone metody w edukacji specjalnej $i$ wtaczajacej [Best practices in special and inclusive education]. Gdańsk: Harmonia (Harmonia Publishing House).

Olechowska A. (2016). Specjalne potrzeby edukacyjne [Special educational needs]. Warszawa: Wydawnictwo Naukowe PWN SA (Scientific Publishing House PWN SA).

Paiva de Oliveira, A. R., Abreu de van Munster, M., \& Gonçalves, A. G. (2019). Universal design for learning and inclusive education: A systematic review in the international literature. Revista Brasileira de Educacao Especial Bauru (Bauru Brazilian Journal of Special Educatio), 25(4), 627-640.

Scot, L. A. (2018). Barriers with implementing a universal design for learning framework. Inc, 6(4), 274-286.

Szempruch, J. (2012). Nauczyciel w warunkach zmiany spolecznej i edukacyjnej [Teacher in the social and educational change environment]. Kraków: Oficyna Wydawnicza "Impuls" ('Impuls' Publishing House).

Szumski, G. (2019). Zróżnicowane grupy uczniów - jakie problemy? [Diversified groups of students-What problems?]. In I. Chrzanowska, G. Szumski (Eds.), Edukacja właczająca w przedszkolu i szkole [Inclusive education at kindergarden and school] (pp. 62-69). Warsaw: Wydawnictwo FRSE (FRSE Publishers). 
Open Access This chapter is licensed under the terms of the Creative Commons Attribution 4.0 International License (http://creativecommons.org/licenses/by/4.0/), which permits use, sharing, adaptation, distribution and reproduction in any medium or format, as long as you give appropriate credit to the original author(s) and the source, provide a link to the Creative Commons license and indicate if changes were made.

The images or other third party material in this chapter are included in the chapter's Creative Commons license, unless indicated otherwise in a credit line to the material. If material is not included in the chapter's Creative Commons license and your intended use is not permitted by statutory regulation or exceeds the permitted use, you will need to obtain permission directly from the copyright holder. 